Bakgrunn: Lightning Process (LP) er en kursbasert treningsmetode som er under debatt når det gjelder behandling av CFS/ME.

Hensikt: Denne kvalitative studien har som mål å styrke kunnskapen om CFS/ME-pasienters ulike erfaringer med LP.

Metode: Studien undersøker hva som skiller beskrivelsene til to pasientgrupper som hadde ulike erfaringer med metoden. Den ene gruppen erfarte at LP virket positivt på deres tilstand, mens den andre erfarte at metoden ikke virket eller virket negativt. Analysen er basert på beskrivelsene til 22 informanter der 13 fortalte om en positiv virkning og ni om ingen eller negativ virkning. Erfaringene ble formidlet fra ti til 26 måneder etter avsluttet kurs.

Resultater: Studien har identifisert tre forhold som skiller beskrivelsene til informantene i de to gruppene: (a) responsen på teorigrunnlag og de grunnleggende prinsipper i LP, (b) erfaringer med kursledelsen og (c) kroppens respons på LP.

Konklusjon: Materialet reiser flere problemstillinger for det videre arbeidet med å forstå CFS/ ME-pasienters ulike erfaringer med LP. Det argumenteres for at det spesielt er behov for å rette oppmerksomheten mot kommunikasjonen mellom kursleder og kursdeltaker.
CFS/ME patients' different experiences with Lightning Process

Background: Lightning Process (LP) is a course-based training program which is under debate as a treatment for CFS/ME.

Method: This qualitative study aims to provide more insight into CFS/ME patients' different experiences with LP. We have investigated the accounts of two patient groups that described different impact of LP on their CFS/ ME. One of the groups described a positive impact of LP, while the other reported that the program was without impact or had a negative impact on their condition. The analysis is based on the account of 22 informants where 13 described a positive impact while 9 described a lack of impact or that LP had a negative impact on their condition. The accounts were given 10 to 26 months after the course.

Results: The accounts of the two groups differed along three dimensions; (a) the response to the theory and fundamental principles in LP, (b) how they experienced the supervision on the course, and (c) their body's response to LP.

Conclusion: Further questions regarding CFS/ME-patients different experiences with LP are raised through this analysis. Our argument is that it is particularly necessary to pay more attention to the communication between the LP-instructor and the course participant.

Keywords: Patient, Complementary and Alternative Medicine, Qualitative study 


\section{»CFS-/ME-pasienters ulike erfaringer med Lightning Process}

Forfattere: Anne-Grete Sandaunet og Anita Salamonsen

\section{NøKKELORD}

- Pasient

- Alternativ behandling

- Kvalitativ studie

\section{BAKGRUNN}

Lightning Process (LP) har fått stor medieoppmerksomhet i Norge som en potensiell kur for CFS/ME (Chronic Fatigue Syndrom/Myalgisk Encefalopati). LP er utviklet av den britiske osteopaten Phil Parker og er en treningsmetode som formidles på et tredagers kurs. Parker framhever metodens kurative effekt (1: kap 4). Basert på egne evalueringer av LP hevder han at omtrent 80 prosent av kursdeltakerne blir fri fra tilstanden de kom for når de har deltatt på kurs (2).

LP debatteres hyppig i media og i ulike pasientfora. Vi vet fra slike kilder at kursdeltakere beskriver svært ulike virkninger av LP, fra helbredelse til betydelig svekket funksjonsnivå. Det er så langt ikke publisert forskningsbasert kunnskap om metodens effekt, verken kli- niske studier eller deskriptive studier av pasienterfaringer. Helsepersonell har derfor lite informasjon å støtte seg til i kommunikasjon med pasienter ut over at LP er et udokumentert tilbud. En pågående britisk randomisert kontrollert pilotstudie er foreløpig det eneste eksempelet på systematisk utforsking av metoden (3). Det har samtidig vært en tilnærming til LP i deler av norsk helsevesen, og det finnes eksempler på at NAV har gitt økonomisk støtte til kursdeltakelse (4). Forskningsbasert kunnskap om LP er nødvendig fordi tilgjengelig informasjon er basert på anekdotisk og svært sprikende materiale. Samtidig anvendes metoden av pasientgrupper som opplever begrensede behandlingstilbud innenfor det offentlige helsevesenet.

LP er ikke spesielt utviklet for CFS/ME-pasienter, men gruppen utgjør en stor andel av norske kursdeltakere. CFS/ ME karakteriseres av alvorlig utmattelse eller energisvikt i kombinasjon med symptomer som muskelplager, søvnforstyrrelser, hodepine, hukommelsesog konsentrasjonsproblemer (5).
Tilstanden medfører ofte et betydelig funksjonstap, og kan ha konsekvenser som berører identitet og mestring (6). Nyere forskning har pekt i retning av en immunologisk årsak til CFS/ ME (7). Internasjonale studier varierer i sine anslag om utbredelse av tilstanden, fra opptil 1 prosent av befolkningen (7), til $0,1-0,2$ prosent ved bruk av noe strengere kriterier (8).

\section{Hva tilfører denne artikkelen?}

Artikkelen viser at kommunikasjon og tillit var viktige temaer i to grupper med ME-pasienter som hadde erfaring med metoden Lightning Process.

\section{Mer om forfatterne:}

Anne-Grete Sandaunet er utdannet $d r$. polit i sosiologi. Hun er ansatt som førstelektor ved Institutt for Sosiologi, Statsvitenskap og Samfunnsplanlegging ved Universitetet i Troms $\varnothing$. Anita Salamonsen er utdannet cand. polit i sosiologi. Hun er ansatt som forsker og doktorgradsstipendiat ved Nasjonalt forskningssenter innen komplementær og alternativ medisin (NAFKAM), Institutt for Samfunnsmedisin ved Universitetet i Troms $\varnothing$. Kontaktperson: anne-grete.sandaunetQuit.no. 
Totalt sett mangler det en medisinsk konsensus om hva CFS/ME skyldes og hvordan tilstanden kan behandles. En gjennomgang fra Kunnskapssenteret konkluderte nylig med at kognitiv atferdsterapi og gradert treningsterapi trolig har positiv effekt på noen områder, mens dokumentasjonen for andre tiltak er av lav kvalitet eller helt fraværende (9).

Innenfor LP forklares CFS/ ME med at hjernen og kroppen er fastlåst i negative, ubevisste tankemønstre. LP skal være et hjelpemiddel for å identifisere og erstatte disse. LP er basert på elementer fra blant annet rer og gir respons til deltakerne mens prosessen læres (1). Oppfølgingssamtaler er inkludert i kurset, men det er opp til den enkelte deltaker å ta initiativ til dette (1:115). Som kursdeltaker skal man akseptere at kurslederen vet hva som er best for kursdeltakerne (1:117). Manglende eller negativ innvirkning på tilstanden blir forklart med at deltakerne ikke «har anvendt treningsprogrammet slik det var konstruert for å virke» (1:25, vår oversettelse). Den enkeltes eget ansvar for å lykkes med metoden er ett sentralt tema i debatten rundt LP og CFS/ME.

Denne kvalitative studien

\section{Forestillingen om et næert samvirke mellom kropp og sjel er sentralt i LP's teorigrunnlag}

hypnoterapi, nevrolingvistisk programmering og osteopati. Forestillingen om et nært samvirke mellom kropp og sjel er sentralt i LP's teorigrunnlag. I følge Parker kan LP virke positivt på mentale prosesser som påvirker en nevrofysiologisk ubalanse, og positiv effekt kan inntre raskt (1).

LP består av mentalt arbeid som foregår trinnvis og kombineres med et skrittmønster og tilhørende kroppsbevegelser (1, 10). Forventningen om at endring er mulig og motivasjonen for endring tillegges avgjørende betydning for at endringene settes i gang. Parker presenterer LP som et treningsprogram og understreker kursdeltakerens aktive rolle i å oppnå effekt (1).

Kurslederne er utdannet og lisensiert via The Phil Parker Training Institute i London. Kurslederen presenterer teorigrunnlaget og de grunnleggende prinsippene i LP, samt assiste- søker å bidra til en første forskningsbasert forståelse av CFS/ ME-pasienters svært ulike erfaringer med LP. Vi har undersøkt hva som skiller beskrivelsene til to pasientgrupper som beskrev ulik virkning av metoden. Den ene gruppen hadde erfart at LP virket positivt på deres tilstand, mens den andre hadde erfart at metoden ikke virket eller virket negativt.

\section{METODE OG MATERIALE}

Studien er del av en større kvalitativ undersøkelse av CFS/ ME-pasienters erfaringer med LP og annen behandling (11). Datagrunnlaget består av dybdeintervjuer og skriftlig formidlete pasienterfaringer. Kvalitativ forskning på årsaker til bruk av alternativ behandling, samt positive og negative pasienterfaringer med bruk kan bidra til å initiere og kvalitetssikre potente kvantitative studier av ulike alternative behandlingsmetoder.

\section{Rekruttering}

Informanter ble rekruttert via Nasjonalt forskningssenter innen komplementær og alternativ medisin (NAFKAM) og deres Register for eksepsjonelle sykdomsforløp (RESF), samt et nettforum for CFS/ ME-pasienter. RESF er opprettet for å registrere pasientdefinerte uvanlig gode og dårlige sykdomsforløp etter bruk av alternativ behandling. Registreringer skjer gjennom utfylling av et spørreskjema som inkluderer åpne spørsmål der pasienten beskriver sine erfaringer (12). I forskningssammenheng argumenteres det for at denne typen «uvanlige» eksempler kan være informasjonsrike og viktig grunnlag for forskning (13).

Alle CFS/ME-pasienter registrert etter bruk av LP medio april 2009 (N=24) fikk en skriftlig forespørsel fra daglig leder i RESF om å delta i intervju. Interesserte ble bedt om å henvende seg til førsteforfatter. Kun positive forløp var registrert ved studiens oppstart. For å få et bredere utvalg som inkluderte deltakere som ikke hadde erfart en positiv virkning av LP henvendte vi oss til et nettforum for CFS/ME-pasienter. Vi fikk tillatelse til å etterspørre henvendelser fra LP-deltakere som ikke hadde gode erfaringer med metoden. Interesserte ble også her bedt om å henvende seg til førsteforfatter. Studien og RESF er tilrådt av Norsk Samfunnsvitenskapelig Datatjeneste og Regional Etisk Komité.

\section{Utvalg}

Studien inkluderer 13 tidligere kursdeltakere som beskrev en positiv virkning av LP og ni som hadde erfart at metoden ikke virket eller hadde negativ innvirkning. De 13 «best 
cases» ble rekruttert fra RESF. Disse rapporterte en vesentlig forbedring av CFS/ME som de spesifikt forklarte med sin bruk av LP. Hva en "vesentlig forbedring» innebar varierte. For noen var det at de kom seg ut av en sengeliggende tilværelse og igjen kunne delta i dagliglivet, for andre var det skrittet fra å kunne delta i dagliglivet til å gå ut i jobb eller studier. Seks informanter ble rekruttert gjennom nettforumet. Disse la ved inklusjonen vekt på at LP ikke hadde virket for dem, men at de heller ikke hadde erfart at metoden virket negativt på deres tilstand.

Artikkelens andreforfatter hadde etisk tillatelse til å bruke nyere data fra RESF. På analysetidspunktet inneholdt RESF tre registreringer fra CFS-/ ME-pasienter som hadde erfart negativ virkning av LP (14). Vi vurderte denne informasjonen som viktig for å få et bredest mulig bilde av kursdeltakeres erfaringer med LP. Anonymiserte tekstutdrag fra registerets spørreskjema om behandlingserfaringer ble derfor inkludert for disse tre pasientene. Deltakerne med negative erfaringer rapporterte om et vesentlig nedsatt funksjonsnivå som de knyttet til sin bruk av LP. Sammen med de seks informantene fra nettforumet utgjør de en kategori på ni deltakere som ikke hadde erfart en positiv virkning av LP.

Samtlige 22 informanter hadde gjennomført LP-kurs i perioden juni 2007 til oktober 2008. Elleve hadde reist til England på kurs mens elleve hadde tatt kurset i Norge med engelskspråklige kursledere. Av disse hadde tre fått instruktøren hjem til seg. En informant var mann og resten kvinner, og de var i alderen 20-55 år. Nesten alle hadde høyere utdanning. Alle informantene oppga at de hadde fått fastsatt en CFS/MEdiagnose av helsevesenet.

\section{Gjennomføring}

De 13 «best cases» og de seks informantene fra nettforumet ble intervjuet. Målet var å oppnå innsikt i deres erfaringer med LP, deres erfaringer med behandling mer generelt, samt deres erfaringer med CFS/ME. Intervjuene ble gjennomført i perioden mai til august 2009 , fra ti måneder til to år etter avsluttet LP-kurs. Intervjuene varte fra 30 til 120 minutter. Intervjueren (AGS) introduserte hvert tema ved hjelp av åpne spørsmål og hadde så oppfølgingsspørsmål til det informantene fortalte. De tre "worst cases» hadde svart på RESF's spørreskjema om behandlingserfaringer fra ni til 26 måneder etter avsluttet LP-kurs. Dette søkelsens problemstilling. Den selekterte empirien ble deretter kodet og kategorisert. Framgangsmåten har felles trekk med Grounded Theory (15) og knytter spesielt an til Days gjennomgang (16). Her blir metodens induktive preg tonet ned og det tas høyde for at forskerens forforståelser preger de ulike delene av forskningsprosessen. Et viktig utgangspunkt for denne studien var ønsket om å utforske hvordan kursdeltakere kan erfare ulik virkning av LP. Dette har forankring i en relasjonell forståelse av menneskelig handling og erfaring der antakelsen er at LP anvendes i en kontekst der både biologiske forutsetninger, personlighetstrekk og sosiale og kulturelle rammer blir av betydning for deltakernes erfaringer. Parkers vektlegging av at alle har like forutsetninger for å lykkes med metoden med nok innsats, settes i et kritisk lys. Denne for-

\section{Jeg ble jo friskere allerede da, ting begynte å skje bare fordi jeg}

\section{fikk tro og håp, ikke sant.}

skriftlige materialet ga et godt innblikk i informantenes erfaringer med LP. Det var mindre omfattende når det gjaldt øvrige temaer som ble tatt opp i intervjuene.

\section{Analyse}

De delene av intervjumaterialet og spørreskjemaene som omhandlet deltakernes erfaringer med LP ble skilt ut for videre bearbeiding og utgjorde det Tjora betegner som en «temasortert empiri» (9: 132). Utvelgelsen foregikk strategisk og med utgangspunkt i under- forståelsen blir av betydning i utformingen av studien, i intervjusituasjonen og i bearbeidelsen av materialet.

\section{RESULTATER}

Gruppenes ulike erfaringer kan knyttes til tre hovedpunkter: a) Responsen på teorigrunnlag og grunnleggende prinsipper i LP, b) kursledelsen og formidlingen av LP og c) kroppens respons på LP.

\section{Responsen på LP}

I tråd med kravene til deltakelse på LP-kurs beskrev nesten alle 
informantene seg som svært motiverte for LP-metoden før kursstart. Informantene som beskrev en positiv virkning av LP formidlet en opplevelse av at de gjennom introduksjonen til metoden fikk en forklaring på hva CFS/ME var. Dette ga mening i forhold til deres egen opplevelse av tilstanden. Noen beskrev introduksjonen til LP som en «aha-opplevelse», og enkelte fortalte at de hadde fått denne opplevelsen straks de hørte om metoden. For eksempel fortalte en at "Jeg ble jo friskere allerede da, ting begynte å skje bare fordi jeg fikk tro og håp ikke sant». For andre skjedde dette i løpet av kursdagene. Gruppen som beskrev manglende eller negativ virkning skilte seg fra gruppen over ved at ingen skisserte et liknende løft i møtet med

\section{ME-folelsen forsvant.}

LP. Samtidig ga de heller ikke uttrykk for negativ respons på teorigrunnlag og grunnleggende prinsipper i LP. Forskjellen handler om at de ikke formidlet en tilsvarende opplevelse av å få økt forståelse av sin egen tilstand i møtet med LP.

\section{Kursledelsen og formidlingen av LP}

Det andre skillet mellom gruppene er knyttet til erfaringer med kursledelsen og formidlingen av LP. Informantene som beskrev positiv virkning av LP ga uttrykk for at det ble etablert et tillitsforhold til kurslederen. De vektla kurslederens lydhørhet for deres individuelle utfordringer, samtidig som kurslederen var den som styrte kurssituasjonen. En sa: «Jeg kjente at ... ting skulle ikke skje på mine premisser $\mathrm{da}$, men hun skulle ikke tvinge meg til å gjøre ting jeg ikke klarte heller». Flere fortalte om en tett dialog med kursleder i etterkant av kurset der de fikk veiledning på konkrete utfordringer i anvendelsen av LP. Noen kommenterte at de «ikke visste hvor mange e-poster de hadde utvekslet» med kurslederen. Andre understreket hvor viktig den spesielle kurslederen var for deres positive erfaring med LP. Flere sa at de ikke turte å anbefale andre kursledere.

Informanter som beskrev manglende eller negativ virkning av LP ga inntrykk av at det ikke ble opparbeidet et tilsvarende tillitsforhold til kurslederen. Informantene kommenterte at kurslederen kjørte sitt opplegg og at det i liten grad ble gitt individuell respons. En sa at deltakere på hennes kurs ikke fikk komme til orde med spørsmål. Flere vektla at det ble vanskelig å relatere LP og de eksemplene som ble brukt av kurslederen til deres egen situasjon og de fikk problemer med å bruke metoden hjemme. En av disse fortalte at hun hadde fått tilbakemelding på kurset om at hun "virkelig hadde forstått metoden». Informanten som opplevde at det var vanskelig å komme til orde med spørsmål lot være å kontakte kurslederen i etterkant fordi hun mente hun ville få tilbakemelding om at hun «ikke ville nok».

En informant som beskrev forverring av CFS/ME etter bruk av LP, påpekte manglende kunnskap hos kurslederen. Informanten hadde en immunologisk sykdom og fikk under en oppfølgingstime med kurslederen beskjed om å spise mat hun ikke tålte. Hun sa hun trodde kurslederen «neppe visste hva sykdommen er». Andre hadde erfart påtrykk fra kursleder om å overprøve sine kroppslige signaler. En sa at han i oppfølgingstimer med kurslederen ble "påvirket til å tro at tilbakefallene kom fordi jeg ikke gjorde øvelsene ordentlig».

\section{Responsen fra egen kropp}

Responsen fra egen kropp er en tredje dimensjon hvor beskrivelsene i de to gruppene skiller seg fra hverandre. Deltakere i gruppen som beskrev en positiv virkning av metoden la vekt på en opplevelse av at kroppen responderte «annerledes» på belastning enn den pleide da de tok i bruk LP og at «MEfølelsen forsvant». De fortalte om en positiv kroppslig respons på LP både i løpet av kurset og etterpå. En som hadde vært sengeliggende i 15 måneder før kurset beskrev hvordan hun våknet uthvilt andre kursdag og klarte å gå på badet. Informantene fortalte at de opplevde en annen form for tretthetsfølelse, for eksempel at «dette var jo sånn det kunne være før jeg ble syk, det var ikke utmattelse, jeg var rett og slett søvnig». Flere opplevde det som vanskelig å sette nærmere ord på hvordan kroppen responderte, men noen refererte til en opplevelse av noe som «løsnet» eller «slapp». Informanter som beskrev en manglende innvirkning på sin tilstand fortalte at kroppen ikke responderte. En sa at LP ikke «framkalte de fysiske effektene på kroppen min, sånn som det ble beskrevet at det skulle gjøre». Manglende virkning ble av en deltaker konkretisert med at det var noe som «stoppet opp» underveis i prosessen. Deltakere som opplevde negativ innvirkning beskrev et vesentlig 
nedsatt funksjonsnivå, som for to av dem innebar at de etter kurset gikk fra å kunne være oppe til å bli sengeliggende store deler av døgnet.

\section{DISKUSJON}

Informantene i de to gruppene formidlet en ulik respons på teorigrunnlaget og grunnleggende prinsipper i LP, ulike erfaringer med kursledelsen og ulik kroppslig respons på LP. Opplevelsen av å få økt forståelse av egen tilstand da de ble introdusert til teori og grunnleggende prinsipper i LP, var betegnende for gruppen som beskrev en positiv virkning. Opplevd bedring som følge av økt innsikt i tilstanden er også beskrevet i tidligere forskning på CFS-/ME-pasienter (6). Når det gjelder LP, vil det være nødvendig å se nærmere på når LP bidrar med økt innsikt, for eksempel om det gjelder visse grupper av CFS-/ME-pasienter. Sammenfallet mellom å oppleve mer innsikt i egen tilstand og å oppleve bedring bidrar også til å sette ytterligere søkelys på hva det kan innebære å leve med tilstander der mye er uavklart når det gjelder årsaker og behandling (17).

Etableringen av et tillitsforhold til kursleder skilte gruppene når det gjaldt erfaringene med kursledelsen og ble formidlet av gruppen som beskrev en positiv virkning. Tillit er fra før anerkjent som viktig for et positivt terapeutisk forhold (18), og det antydes også en indirekte sammenheng med behandlingsresultater (19). Materialet viste at lydhørhet fra kursleders side, sammen med konkret respons på utfordringer som informantene møtte $\mathrm{i}$ anvendelsen av metoden, var viktige elementer i oppbygningen av tillit. Beskri- velsene er i tråd med tidligere forskning som har vist at aktiv respons fra behandler er viktig for etablering av tillit (19). Mer forskning på kurslederes formidling av LP og kursdeltakernes erfaringer med dette kan representere en innfallsvinkel til å forstå hvordan tillit etableres eller at det ikke oppstår et tillitsforhold. deltakerne vektlegger i intervjusituasjonen eller i utfylling av spørreskjema, kan ha blitt mindre vektlagt på kurstidspunktet eller i møtet med en annen tilhører. Slike momenter kan reise spørsmål om resultatene sier noe om disse informantenes «subjektive realitet» når det gjelder deres erfaringer med LP. Vi opererer imidlertid innenfor

\section{Det var ikke utmattelse, jeg var rett og slett sovnig.}

Det tredje skillet mellom gruppene var beskrivelser av ulik kroppslig respons på LP. Formidlingen av en positiv kroppslig respons bidrar til å rette oppmerksomheten mot hvilke virkningsmekanismer som involveres når kursdeltakere opplever virkning av LP. Materialet understreker dermed betydningen av å få mer kunnskap om forholdet mellom erfaring og biologi. Dette er også påpekt i nyere medisinsk forskningslitteratur (20). Forskning på alternative behandlingsformer viser at pasienter anser positive kroppslige erfaringer som et viktig element i evaluering og valg av behandling (21).

Beskrivelser av manglende helsefaglig kunnskap hos kursleder og opplevd press om ignorering av kroppslige symptomer og om å lykkes, indikerer at det også er etiske aspekter ved LP som bør vises videre oppmerksomhet.

I fortolkningen av dette materialet må vi ta høyde for at forhold som forskernes forforståelser, intervjusituasjonen og spørreskjemaets utforming får betydning for det vi omtaler som studiens resultater. Videre må vi også ta høyde for at det en metodologisk tradisjon der de utforskedes subjektive realitet ikke anses som direkte tilgjengelig og der resultatene av en studie alltid vil være kontekstavhengig og også influert av forskerens forforståelser (22). Det viktige blir å utøve refleksivitet gjennom forskningsprosessen (23) ved å vise hvilke valg som er gjort underveis og hvorfor, samt å redegjøre for forskningssituasjonen (24). Det er med utgangspunkt i dette metodologiske ståstedet at materialet i denne studien er samlet inn og fortolket.

I diskusjoner om behandlingers virkemåte blir resultater fra eksplorative studier av hypotesegenererende art (25). Vår undersøkelse løfter fram noen aspekter ved CFS-/ME-pasienters ulike erfaringer med LP som kan danne utgangspunkt for videre forskning og refleksjon.

\section{KONKLUSJON}

I denne eksplorative studien fant vi at økt forståelse av egen tilstand, tillit til kursleder og positiv kroppslig respons skilte CFS-/ME-pasienter som erfarte at LP virket positivt fra CFS-/ ME-pasienter som erfarte ingen eller negativ virkning. Studien 
reiser flere problemstillinger for videre forskning. Vi mener at den spesielt viser et behov for forskningsmessig oppmerksomhet mot kommunikasjon og tillit i pasientkurslederrelasjonen. De etiske sidene ved at LP-kursledere fokuserer på den enkelte kursdeltakers ansvar for å oppnå positive resulta- ter bør også utforskes videre. Når det gjelder kliniske implikasjoner, antas kvalitative studier å være av begrenset betydning (26). Det finnes samtidig eksempler på at kvalitativ forskning har bidratt konkret til utvikling av vurderingsverktøyer og kommunikasjonsveiledere (26). Denne kvalitative studien av
CFS-/ME pasienters ulike erfaringer med LP gir innsikt i en lite utforsket metode som vurderes av et økende antall pasienter. Denne innsikten kan være relevant for helsearbeidere som i sin kliniske virksomhet kommuniserer med CFS-/ME-pasienter som har tatt LP-kurs eller vurderer dette.

\section{LITTERATURLISTE}

1. Parker P. The Lightning Process. The Complete Strategy For Success: Nipton Publishing; 2007.

2. Lightning Process. CFS/ME /Chronic Fatigue Syndrome and Myalgic Encephalopathyl. Thoughts on the illness, by Phil Parker. The Lightning Process: 2011. Tilgjengelig fra www.lightningprocess.com/CFS-ME-Home.INedlastet 24.02.20111.

3. Crawley E. SMILE - Specialist Medical Intervention \& Lightning Evaluation. Assessing the feasibility and acceptability of comparing the Lightning Process with specialist medical care for Chronic Fatigue Syndrom or Myalgic Encephalopathy - pilot Randomised Controlled Trial [Protokoll]. University of Bristol, 2011

4. Nilsen L. Dekket omstridt LP-kurs. Dagens Medisin. Oslo: Bonnier; 2009 5. Soderlund A, Skoge A, K M. «l could not lift my arm holding the fork». Living with chronic fatique syndrome. Scandinavian Journal of Primary Health Care. 2000;18:165-9.

6. Larun L, Malterud K. Identity and coping experiences in Chronic Fatique Syndrome: A synthesis of qualitative studies. Patient Education and Counseling. 2007;69:20-8.

7. Fluge $\emptyset$, Bruland 0 , Risa K, Storstein A, Kristoffersen E, Sapkota D, et al. Benefit from B-Lymphocyte Depletion Using the AntiCD20 Antibody Rituximab in Chronic Fatique Syndrome. A DoubleBlind and Placebo-Controlled Stduy. PLoS ONE. 2011;6(10):e26358.

8. Nacul L, Lacerda E, Pheby D, Campion P, Molokhia M, Fayyaz S, et al. Prevalence of myalgic encephalomyelitis/ chronic fatique syndrome (ME/CFS) in three regions of England: a repeated cross-sectional study in primary care. BMC Med. 2011;9:91.
9. Nasjonalt kunnskapssenter for helsetjenesten. Behandling av kronisk utmattelsessyndrom CFS/ME, Notat. Oslo: Nasjonalt kunnskapssenter for helsetjenesten; 2011.

10. Lightning Process. What is it? The Lightning Process; 2011. Tilgjengelig fra www.lightning process.com/What-is-it. (Nedlastet 28.02.2011).

11. Sandaunet A. Komplementær og alternativ medisin: behandlerroller. samhandlingsmønstre og betydning for brukerne [Protokoll]. Universitetet i Tromsø; 2009

12. Fønnebø V, Drageset B, Salamonsen A. The NAFKAM International Registry of Exceptional Courses of Disease related to the use of CAM. Global Advances in Health and Medicine. 2012;1(1):7-9.

13. Patton M. Qualitative Research \& Evaluation Methods (3. utgave). Thousand Oaks, California: SAGE Publications; 2002

14. Fønnebø V, Drageset B, Salamonsen A. Worst cases reported to the NAFKAM International Registry of Exceptional Courses of Disease Global Advances in Health and Medicine. 2012;1(1):28.

15. Glaser B, Strauss A. The discovery of grounded theory: strategies for qualitative research. New York: Aldine de Gruyter; 1967.

16. Day I. Grounded Theory. I Seale, C.,Gobo, B., Gubrium, JF., Silverman, C (red). Qualitative Research Practice. SAGE: Wiltshire. 2007

17. Nettleton S, O'Malley L, Watt I, Duffey P. Enigmatic Illness: Narratives of Patients who live with Medically Unexplained Symtoms. Social Theory and Health. 2004:2:47-66.

18. Keating N, Tejal G, Orav E, Bates D, Ayanian J. Patient Characteristics and Experiences Associated With Trust in Specialist Phyysicians. Archives of Internal Medicine. 2004;164:1015-20.
19. Rowe R, Calnan M. Trust relations in health care - the new agenda. European Journal of Public Health. 2006;16(1):4-6. 20. Getz L, Kirkengen A, Ulvestad E. Menneskets biologi - mettet med erfaring. Tidsskrift for Den norske legeforening. 2011;131(7):683-7.

21. Salamonsen A, Kruse T, Eriksen S. Modes of Embodiment in Breast Cancer Patients Using Complementary and Alternative Medicine. Qualitative Health Research. 2012; under publisering. 22. Järvinen M, Mik-Meyer, N. Kvalitative metoder i et interaktionistisk perspektiv : interview, observationer og dokumenter København: Reitzel; 2005. 23. Alvesson M, Skjöldberg K. Reflexive Methodology. London: SAGE Publications; 2000 .

24. Thaagaard T. Systematikk og innlevelse. En innføring i kvalitativ metode. Bergen: Fagbokforlaget; 2008 25. Gobo G. Doing ethnography. Los Angeles: SAGE Publications; 2008. 26. Sandelowski M. Using Qualitative Research. Qualitative Health Research. 2004:14(10):1366-86. 